Prezentowana niżej polemika pt. Debata o socjologii międzynarodowej ukazała się w „Contemporary Sociology. A Journal of Reviews" 40, nr 4. Punktem wyjścia do dyskusji między Piotrem Sztompką i Michaelem Burawoyem była książka z 2010 roku Facing an Unequal World: Challenges for a Global Sociology (t. 1: Introduction, Latin America and Africa, ss. 316; t. 2: Asia, ss. 362; t. 3: Europe, and Concluding Reflexions, ss. 296), pod redakcją Michaela Burawoya, Mau-kuei Changa i Michelle Fei-yu Hsieh, wydana w Tajpej przez Institute of Sociology at Academia Sinica, Council of National Associations of the International Sociological Association \& Academia Sinica.

The polemics between Piotr Sztompka and Michael Burawoy was originally published in Contemporary Sociology. A Journal of Reviews no 40/4 as Debate on International Sociology. The starting point of discussion between Piotr Sztompka and Michael Burawoy was the publication entitled Facing an Unequal World: Challenges for a Global Sociology (Volume One: Introduction, Latin America and Africa, 316 pp.; Volume Two: Asia, 362 pp.; Volume Three: Europe, and Concluding Reflections, 296 pp.), edited by Michael Burawoy, Mau-kuei Chang and Michelle Fei-yu Hsieh (Taipei, Taiwan: Institute of Sociology at Academia Sinica, Council of National Associations of the International Sociological Association \& Academia Sinica, 2010).

Wyrażenia kluczowe: Michael Burawoy; Międzynarodowe Towarzystwo Socjologiczne; dominacja; kolonializm;

imperializm; globalizacja; Zachód; lokalność; socjologia globalna; utopia

\title{
Kolejna socjologiczna utopia
}

\section{Piotr Sztompka}

Recenzowane materiały prezentują dorobek konferencji Międzynarodowego Towarzystwa Socjologicznego (International Sociological Association, dalej: ISA) w Tajpej w 2009 roku, zorganizowanej przez Tajwańskie Towarzystwo Socjologiczne (Taiwanese Sociological Association) i uczelnię Academia Sinica. Spotkanie to odbyło się z inicjatywy ówczesnego wiceprezesa ISA, a obecnego prezesa tej organizacji, Michaela Burawoya. Uczestniczyło w nim 60 uczonych z 43 krajów, a w ciągu trzydniowych obrad zaprezentowano 53 referaty, wydane jako materiały konferencyjne (Burawoy, Chang, \& Fei-yu Hsieh, 2010).

Struktura omawianego opracowania może wydać się dziwna jak na pozycję z zakresu socjologii, jedynym bowiem widocznym kryterium systemowym jest układ geograficzny. Poszczególne części noszą tytuły takie, jak: Ameryka Łacińska, Afryka, Azja Zachodnia, Azja Pacyficzna, Europa Zachodnia, Pótnocna i Południowa czy Europa Wschodnia i Środkowa. Kolejność rozdziałów, z których składają się powyższe bloki, jest w zasadzie całkowicie przypadkowa i pozbawiona klucza tematycznego. Zresztą systematyka geograficzna wydaje się miejscami niejasna. I tak wśród opracowań z Europy Zachodniej próżno szukać materiałów z Niemiec, kolebki socjologii klasycznej, z Włoch, Szwecji czy Norwegii. Jeszcze większe zdumienie budzi pominięcie Ameryki Północnej, skoro niniejsze zestawienie ma być pozycją z zakresu socjologii światowej, a znaczenie socjologii amerykańskiej i kanadyjskiej nie może budzić wątpliwości. Co prawda, wśród autorów znalazł się Amerykanin, 
Michael Burawoy, lecz jego wkład ogranicza się do rozdziału wstępnego (Burawoy, 2010), oraz Amerykanka, Jan Marie Fritz, autorka trzech stron zawierających „wnioski końcowe” (Fritz, 2010), którą Burawoy traktuje jako przedstawicielkę socjologii amerykańskiej.

Uwzględnienie dorobku badaczy z wszystkich kontynentów z wyjątkiem Ameryki Północnej może mieć związek z istnieniem międzykontynentalnej koalicji socjologów, którzy ignorują - lub odrzucają - socjologię amerykańską i pracują nad alternatywnymi metodami, pojęciami, modelami i teoriami; nie tylko odmiennymi, lecz również zasadniczo lepszymi od dotychczasowych. Mamy do czynienia z rewolucyjną zmianą paradygmatu, której zasięg obejmuje nauki socjologiczne - o ile nie całe społeczeństwo globalne.

Ta konkluzja znajduje potwierdzenie w treści materiałów konferencyjnych, liczących około tysiąca stron. Omawiane opracowanie jest dotychczas obszerniejszym podsumowaniem koncepcji, która od dłuższego czasu zyskuje popularność wśród członków ISA, a której najznamienitszym promotorem stał się Michael Burawoy. Sprowadza się ona do trzech twierdzeń o charakterze analitycznym i normatywnym.

Po pierwsze, światową socjologię zdominowali badacze z krajów zachodnich (północnoamerykańskich i europejskich, czyli w skrócie euroamerykańskich), co samo w sobie jest szkodliwe dla tej dyscypliny. Po drugie, poza Stanami Zjednoczonymi i Europą kształtują się alternatywne, lokalne inicjatywy, które pomimo swej znacznej wartości są marginalizowane lub wręcz ignorowane przez grupę amerykańsko-europejską. I wreszcie po trzecie, powyższe dwa twierdzenia przekładają się na postulat nadania socjologii charakteru prawdziwie globalnej dyscypliny, co zapewniłoby równoprawny udział ośrodków naukowych z różnych krajów, a tym samym równorzędność odmiennych perspektyw i wyrugowanie uprzedzeń, o które posądzani są socjolodzy amerykańscy i europejscy.

Piastując przez lata różne stanowiska w ISA, sprzeciwiałem się tej koncepcji. Ubiegając się o funkcję prezesa ISA w 2002 roku, sformułowałem nad wyraz niepoprawne politycznie hasło: „perfekcja jest ważniejsza od równowagi”, co nie przeszkodziło mi w uzyskaniu nominacji na czteroletnią kadencję (w latach 2002-2006) na ogólnoświatowym kongresie w Brisbane. W wydanym przez ISA opracowaniu dotyczącym różnorodności prądów socjologicznych, zatytułowanym ISA Handbook of Diverse Sociological Traditions (Patel, 2010), argumentowałem, że istnieje tylko jedna socjologia, która bada rozmaite środowiska społeczne. Recenzja trzech tomów opracowania Facing an Unequal World daje mi okazję do zaprezentowania bardziej analitycznego i uzasadnionego stanowiska. Rozważmy zatem po kolei każdą z powyższych trzech tez.

\section{Zachodni znaczy zły?}

Różnice dzielące poszczególne kraje świata znajdują wyraz w czterech parach przeciwieństw, które pojawiają się co chwila w tekście: północny - południowy, zachodni - wschodni, rozwinięty - zacofany, centralny - peryferyjny. W niemal wszystkich artykułach powtarza się zarzut dominacji Ameryki i Europy w odniesieniu do każdego z tych

SLH 3/4 2014/2015 | str. 336 
spektrów. O ile chodzi o zasoby ekonomiczne, znaczenie polityczne, siłę militarną, poziom cywilizacyjny, zaawansowanie technologiczne i potencjał kulturalny, nie ma wątpliwości, że poszczególne kraje nie są sobie równe i że w znacznej mierze w dziedzinach tych utrzymuje się - jak na razie - przewaga Zachodu. Wysiłek zmierzający do zmniejszenia nierówności i podniesienia rangi regionów oraz krajów, które znalazły się poza sferą dobrobytu, wolności i innych dobrodziejstw współczesności, jest szlachetną ambicją zasługującą na pochwałę. Jednocześnie wiara, że to kolosalne zadanie może być wykonane rękami socjologów, należących w większości do tzw. bezsilnej elity, trąci megalomanią.

Dlatego autorzy tekstów poruszają się w bardziej przyziemnej tematyce, debatując o nierównościach i dominacji w odniesieniu do nauk socjologicznych i traktując tę problematykę jako odprysk szerszych zjawisk występujących w erze globalizacji. W rzeczywistości autorzy nie zajmują się socjologią zacofania, lecz raczej poddziedziną znaną jako socjologia socjologii, która może przywodzić na myśl węża zjadającego własny ogon. Zastanawiające, jak wiele energii intelektualnej marnuje się na analizy tendencji w naukach socjologicznych w różnych zakątkach globu, na wyszukiwanie nazw instytucji badawczych, tematyki programów dotacyjnych, tytułów egzotycznych czasopism i nazwisk słabo znanych naukowców, których dokonania tak naprawdę nikogo nie interesują. Oto niektóre przykłady zamieszczone w omawianym opracowaniu: Janusz Mucha o Europie Wschodniej (Mucha, 2010), Mau-kuei Chang z zespołem o Tajwanie (Chang, Chang, \& Tang, 2010), Fahad Al-Naser o Kuwejcie (Al-Naser, 2010), Charles Crothers o Nowej Zelandii (Crothers, 2010), Mokong Simon Mapadimeng o RPA (Mapadimeng, 2010). Większość materiałów ma inny charakter i budzi bardziej zasadnicze zastrzeżenia.

Autorzy tych artykułów traktują socjologię socjologii jako dziedzinę ideologiczną, bez skrępowania odrzucając opis i argumentację na rzecz sformułowań ideologicznych, wartościujących i normatywnych. Pomysłowość określeń użytych w tym kontekście jest doprawdy zadziwiająca: zależność naukowa, intelektualny imperializm, amerykański imperializm, socjologiczna kolonizacja, intelektualny kolonializm, dominacja metropolii, teoria metropolii, hegemonia Zachodu, hegemonia Północy, perspektywa Północy zamaskowana jako uniwersalizm, narzucanie koncepcji i teorii przez główny nurt socjologii amerykańskiej i europejskiej, ignorowanie Południa, dominacja języka angielskiego, a nawet „otumanienie Zachodem" - prawdziwie innowacyjny dodatek do slangu antyokcydentalizmu.

Taki język rodzi chaos i nieporozumienia, jest nośnikiem emocji, a nie precyzyjnych znaczeń. Chcąc wprowadzić nieco porządku w tym bałaganie, musimy rozróżnić dwa poziomy, na których stosowane są owe etykiety: instytucjonalny i intelektualny. Nie ulega wątpliwości, że na poziomie instytucji, organizacji i wspólnoty socjologów

„jesteśmy uwikłani w globalny podział na lepszych i gorszych, wynikający z nierównej dystrybucji zasobów materialnych (dochody, fundusze na badania, zobowiązania dydaktyczne, warunki pracy) oraz kapitału społecznego (środowiska zawodowe, mecenat) i kulturalnego (referencje edukacyjne, prestiż uczelni, znajomość języków, publikacje)" (Burawoy, 2010, s. 6). 
Jako polski socjolog nie mam zamiaru zaprzeczać tej asymetrii. W trakcie mojej pierwszej profesury w Stanach Zjednoczonych we wczesnych latach osiemdziesiątych XX w. moje wynagrodzenie było niemal pięćdziesiąt razy wyższe od zarobków, które otrzymywałem w kraju. Osobiście odczuwam sukces postkomunistycznej transformacji w mojej ojczyźnie, jako że dziś zarabiam tylko pięć razy mniej niż moi amerykańscy koledzy. Wracając do tematu, przede wszystkim należy zauważyć, iż socjologia nie jest w omawianym kontekście czymś wyjątkowym. Nierówny podział zasobów w skali globalnej dotyka wszystkie dyscypliny naukowe, w tym nauki przyrodnicze i techniczne; tylko w niektórych krajach istnieją akceleratory cząstek, laboratoria prowadzące badania ludzkiego genomu czy radioteleskopy rejestrujące czarne dziury. Po drugie, ta asymetria jest bezpośrednim skutkiem wspomnianych zasadniczych różnic między innymi w potencjale ekonomicznym, politycznym, militarnym między poszczególnymi krajami. Możemy marzyć o sprawiedliwym podziale zasobów, ale - jak zauważył Syed Farid Alatas - „jako naukowcy nie jesteśmy w stanie zapobiec zależnościom organizacyjnym i materialnym, ponieważ nie kontrolujemy ani instytucji, ani sfery rządowej" (Alatas, 2010, s. 139). Ta uwaga jest zasadna, możemy rwać szaty i potępiać obecny stan rzeczy, ale w większości przypadków jesteśmy bezsilni.

Tymczasem zarzuty o hegemonię, imperializm, kolonizację i kontrolę są również wyrażane w kontekście poznawczym, odnoszą się do warstwy merytorycznej socjologii (teorii, modeli) i charakteru metod badawczych. Tu dochodzimy do jądra omawianego problemu i niezwykle zaciekłego sporu. Niepodważalne fakty historyczne wskazują, że socjologia - tak jak wiele innych wynalazków, dobroczynnych lub szkodliwych - narodziła się w dziewiętnastowiecznej Europie, powołana do życia przez brodatych białych mężczyzn, w większości pochodzenia żydowskiego, mieszkających w Niemczech, Francji i Wielkiej Brytanii. Powtórny rozkwit tej dyscypliny nastąpił na przełomie wieków w Stanach Zjednoczonych. Doktryna socjologii ma więc swe korzenie w pracach naukowców z Europy i Ameryki. Wciąż poruszamy się w ramach tego samego niezwykle nośnego paradygmatu, choć był on wielokrotnie zmieniany i uzupełniany. To intelektualne walory europejskich i amerykańskich standardów, a nie rzekome ambicje imperialistyczne czy propaganda akademicka, przyczyniły się do ich rozpowszechnienia wszędzie tam, gdzie pojawiła się socjologia. Rzecz jasna, kanon ten składa się z wielu nurtów, obejmuje konkurujące ze sobą modele, teorie, koncepcje metodologiczne i procedury badawcze. Każdy z tych elementów powinien być poddany krytycznej analizie, tego bowiem wymaga etos naukowy. Na tym właśnie polega „socjologia krytyczna” według definicji Michaela Burawoya, który umieścił ją wśród czterech elementów swojej typologii, razem z „socjologią zawodową”, „socjologią polityczną” i „socjologią publiczną” (Burawoy, 2010, ss. 15-24, 2005). Tymczasem analizowane opracowanie nie ma nic wspólnego z realizacją postulatów „socjologii krytycznej”, nie da się tu odnaleźć merytorycznych argumentów dotyczących poszczególnych teorii i metod. Nawiasem mówiąc, nie można również natrafić na pozostałe trzy elementy wspomnianej typologii. Zamiast tego mamy do czynienia z namiętną debatą, 
którą określiłbym mianem „socjologii ideologicznej”, i wątpię, aby Burawoy sklasyfikował te wywody jako piąty gatunek socjologii.

Wielu autorów zdaje się podzielać pogląd, że europejskie lub amerykańskie pochodzenie najważniejszych metod socjologicznych - które w takim ujęciu mają za rodzeństwo kapitalizm i imperializm - jest nieusuwalną skazą, a ich rozpowszechnienie na innych kontynentach było wymuszonym rezultatem uzurpacji, porównywalnym z kolonializmem lub, ostatecznie, z neokolonializmem. Być może argument ten dałoby się zastosować, choć z trudem, do religii chrześcijańskiej i przymusowej ewangelizacji. Ale socjologia, przynajmniej w pewnym zakresie, jest nauką, a nie religią; polega na poszukiwaniu prawdy, a nie głoszeniu wiary; stara się uchwycić wzorce, mechanizmy i reguły procesów kształtujących życie społeczne. Mądrzejsi o doświadczenia związane z ruchem antypozytywistycznym nie możemy zaprzeczyć, że pod pewnymi względami socjologia zbliżona jest do nauk przyrodniczych. Czy ktokolwiek w Ekwadorze, Bangladeszu czy na Tajwanie czuje się urażony faktem, że fizyka kwantowa narodziła się w Kopenhadze, Heidelbergu i Berkeley, lub tym, że ludzki genom odtworzony został w Kalifornii? Czy można wątpić w to, że grawitacja działa w Afryce, choć wykryto ją w Wielkiej Brytanii? Dlaczego mamy porzucić uniwersalizm naukowy na rzecz ekstremalnego relatywizmu socjologicznego? Owszem, faktyczne okoliczności życia społecznego różnią się w zależności od rejonu świata, jak również określonego „środowiska socjologicznego” w obrębie jednego kontynentu, regionu lub kraju. A jednak wzorce i mechanizmy ludzkiego zachowania, relacji interpersonalnych, powstawania grup, ustanawiania regut, funkcjonowania władzy i kształtowania się nierówności są takie same, mają charakter uniwersalny. W trakcie podróży do amazońskiej dżungli, której celem było odnalezienie osobliwych odmienności, Claude Levi-Strauss natknął się po prostu na kolejne istoty ludzkie, o czym wspomina w Smutku tropików (Levi-Strauss, 1955). Pomimo niedociągnięć i luk kanoniczna wiedza socjologiczna unaocznia nam istotne prawdy o istotach ludzkich, mężczyznach i kobietach, niezależnie od tego, czy żyją w Paryżu, Quito lub Kioto.

\section{Lokalny znaczy lepszy?}

Rzecz jasna, wiedza socjologiczna - jak każda inna dyscyplina nauki - nie jest wyczerpująca, niepodważalna i absolutnie precyzyjna. Jej rozwój - jak każdej nauki - to niekończący się proces akumulacji obserwacji, koncepcji, hipotez, modeli i teorii. Nie ma powodu, by uznać, że zasoby wiedzy socjologicznej i zestaw narzędzi tej dyscypliny powinny być uzupełniane wyłącznie przez europejskie i amerykańskie ośrodki naukowe. Doświadczenia społeczeństw nienależących do zachodniego kręgu kulturowego mogą być źródłem cennych obserwacji, diagnoz i poglądów. I tak się rzeczywiście dzieje, jako że socjologia jest dziś praktykowana w ponad 140 krajach świata. Wkład tych społeczeństw poszerza i uzupełnia dotychczasowe zasoby wiedzy i potencjał metodologiczny. Wielu socjologów z tzw. drugiego lub trzeciego świata - w żargonie ISA ta część globu to kraje z grup B i C - widać w życiu wspólnoty socjologicznej, pojawia się na kongresach i konferencjach, 
publikuje w czasopismach specjalistycznych, współpracuje z wydawnictwami i uczestniczy w dydaktyce. Ich wkład jest mile widziany, z tym że takie nastawienie wynika nie z powodu ich pochodzenia, ale wartości, które wnoszą do wspólnej puli. Nazwałbym to „programem minimum socjologii globalnej”. I z ochotą pogratulowałbym autorom artykułów omawianych tomów, gdyby skupili się na pracy wykonywanej przez ich kolegów i czasami przez nich samych na przykład w postaci publikacji na łamach czasopism ISA: „International Sociology”, „Current Sociology” czy też innych periodyków akademickich, współpracujących ze środowiskiem socjologów, jak też w serii wydawnictwa Sage na temat socjologii międzynarodowej. Mam tu na myśli doniesienia o fascynujących badaniach empirycznych, postępach teoretycznych czy innowacjach metodologicznych, które dałyby wspomnianym osobom szansę powiększenia puli wiedzy socjologicznej. Dobrze by było, gdyby korzystając z dostępnych metod socjologicznych, zmierzyli się z palącymi problemami społecznymi, na które zwrócił uwagę laureat Nobla w dziedzinie chemii, Yuan-Tseh Lee, w wystąpieniu na konferencji w Tajpej: eksplozją demograficzną, malejącymi zasobami naturalnymi, zmianami klimatycznymi, chorobami cywilizacyjnymi, rozwarstwieniem pomiędzy bogatymi i biednymi, analfabetyzmem, bezrobociem, niezrównoważonym rozwojem (Lee, 2010). Tym właśnie zadaniom poświęca się wielu socjologów nie tylko z Europy i Północnej Ameryki, którzy próbują formułować diagnozy i postulaty społeczne dotyczące tych i podobnych zagadnień.

Tymczasem większość autorów, których artykuły znalazły się w omawianym opracowaniu, nie uczestniczy w opisanej wyżej działalności, przy czym dotyczy to również osób mających na swoim koncie ważne badania wykorzystujące narzędzia głównego nurtu socjologii, przeprowadzone w Indiach, Brazylii, RPA, Izraelu i innych krajach spoza zachodniej strefy kulturowej. Zamiast merytorycznych analiz dostajemy jednak kilkadziesiąt manifestów ideologicznych odnoszących się do mętnych sformułowań w rodzaju „alternatywnej socjologii” czy „lokalnej socjologii”, które miałyby nie tyle uzupełnić, co zastąpić nachalną doktrynę zachodnią. Wszyscy ci badacze grają w rewolucyjnej orkiestrze pod batutą Michaela Burawoya. Promują postulaty, które nazwałbym „programem maksimum globalnej socjologii”. Jeden z orędowników tej koncepcji uważa, że:

„dorobek intelektualny i wzorce kulturowe pochodzące spoza zachodniej sfery kulturowej powinny być uznawane bez wyjątku za potencjalne źródła teorii i koncepcji z zakresu socjologii, co zmniejszyłoby zależność lokalnych ośrodków badawczych od tradycyjnych nurtów socjologii" (Alatas, 2010, s. 139).

Burawoy kreśli stosowny plan działań:

„Rzucenie wyzwania uniwersalizmowi zachodniej socjologii wymagać będzie realizacji następujących etapów: po pierwsze, należy wykazać, że doktryna ta nie odzwierciedla doświadczeń lokalnych populacji, a następnie udowodnić istnienie teorii alternatywnych, które są ignorowane lub marginalizowane przez główne ośrodki badawcze" (Burawoy, 2010, s. 11).

Jeśli chodzi o pierwszą fazę tego projektu, muszę przyznać, że nie rozumiem jej istoty. Czy w niedawno wydanej książce na temat globalnego ocieplenia lord (a więc w domyśle 
imperialista) Anthony Giddens nie porusza kwestii nurtujących mieszkańców Bangladeszu czy Seszeli, krajów zagrożonych rosnącym poziomem oceanów (Giddens, 2009)? Czy teoria stygmatyzacji Ervinga Goffmana jest nieistotna, jeśli chodzi o wyjaśnienie fenomenu pozostałości systemu kastowego w Indiach (Goffman, 1963)? Czy badania dotyczące biedy i bezdomności przeprowadzone w Warszawie, Chicago lub Paryżu nie odzwierciedlają doświadczeń ubogich i bezdomnych, niezależnie od ich narodowości? Analiza socjologiczna, o ile jest godna miana nauki, dotyka uniwersalnych ludzkich problemów i bolączek, dostarczając podstawowych informacji niezbędnych w procesie ich diagnozy, interpretacji, prognozowania i, w sprzyjających okolicznościach, likwidacji, przy czym lokalizacja geograficzna nie ma tu kluczowego znaczenia. Dlatego też nie widzę celowości pierwszej fazy operacji proponowanej przez Burawoya. Być może jest to po prostu ideologiczna retoryka połączona z rewolucyjnym zapałem?

Kluczowe znaczenie ma jednak drugi etap: identyfikacja „teorii alternatywnych”, które mogłyby stanowić przeciwwagę dla działalności „głównych ośrodków badawczych”. Odkąd Akiwowo Akinsolo zaapelował o uznanie „lokalnej socjologii afrykańskiej” (Akiwowo Akinsolo, 1986), nie byłem w stanie zrozumieć tego rodzaju postulatów i poszukiwałem faktycznych przykładów istnienia alternatywnych, lokalnych odłamów socjologii. Ani jednego przykładu nie podał sam Akiwowo, opierając swoje wnioski w zakresie socjologii wiedzy na empirycznych ustaleniach dotyczących afrykańskiej poezji ustnej, przy czym obserwacje te nie są dowodem na istnienie alternatywnej socjologii, ale raczej nowymi argumentami w debacie na temat tradycyjnej socjologii wiedzy spod znaku Marksa i Mannheima. Wypełnia to założenia „programu minimum”, z którym się zgadzam, wypada więc wrócić do poszukiwań elementów „programu maksimum”, czyli rzeczywistych alternatyw w dziedzinie socjologii. Jestem gorliwym czytelnikiem „International Sociology” i w związku z tym przewertowałem numery tego periodyku. Przede wszystkim znalaztem informacje o standardowych metodach socjologicznych (ankiety, kwestionariusze, analiza monograficzna, badanie treści, obserwacja, wskaźniki statystyczne), znajdujących zastosowanie poza zachodnią sferą kulturową i wykorzystywanych jako przesłanki za lub przeciw w odniesieniu do tradycyjnych teorii socjologicznych (funkcjonalizmu, marksizmu, interakcjonizmu symbolicznego, fenomenologii). Zawiedziony tą kwerendą, liczyłem na odnalezienie stosownych informacji w kompilacji pod redakcją Burawoya. Spotkał mnie jednak zawód; ponownie nie natknąłem się na ani jeden przekonujący przykład oryginalnej lokalnej teorii czy metody. Znalazłem za to następującą tezę jednego z najgorętszych orędowników „lokalizacji”, najwyraźniej podcinającego gałąź, na której sam siedzi: „Zasadniczą słabością większości opracowań na ten temat jest nikła liczba alternatywnych teorii i koncepcji, których miejsce zajmuje niekończąca się dyskusja o potrzebie ich sformułowania" (Alatas, 2010, s. 144). To stwierdzenie można uznać za celne podsumowanie wszystkich trzech tomów, których dotyczy niniejsza recenzja. A jednak Alatas podejmuje się znalezienia stosownych przykładów. Jakie są efekty jego poszukiwań? Autor zauważa, iż „w trakcie badań nad komunikowaniem się mieszkańców Azji uczeni z Chin, Japonii i Korei analizowali pewne lokalne pojęcia" (Alatas, 2010, s. 147), takie jak bao, co w języku 
chińskim oznacza 'wzajemność, bian ('zmiana'), guanxi ('sieć wzajemnych powiązań') czy keqi ('uprzejmość). Pojęcia te są po prostu chińskimi ekwiwalentami utrwalonych terminów wypracowanych przez główny nurt socjologii. Czy „lokalna socjologia” to każdy odłam tej dyscypliny, który nie posługuje się językiem angielskim? Czy moja książka na temat zaufania - napisana przez Polaka, opublikowana po raz pierwszy w Cambridge (Sztompka, 1999), wydana w języku chińskim (Sztompka, 2006) - jest częścią socjologii polskiej, brytyjskiej czy może chińskiej? A zatem jestem zmuszony do dalszego szukania wiarygodnego przykładu lokalnej, alternatywnej socjologii.

Zanim jednak wrócę do tego zadania, chciałbym omówić w skrócie aspekt teoretyczny. Termin „lokalny” kryje w sobie wiele znaczeń: pierwsze to „spoza zachodniego kręgu kulturowego (ani amerykański, ani europejski)”; drugie to „ograniczony do jednej cywilizacji”; trzecie to „ograniczony do jednego regionu” i wreszcie czwarte - „ograniczony do jednego państwa narodowego", przy czym właśnie państwo narodowe najmocniej kształtuje w dzisiejszych czasach życie społeczne. Zatrzymajmy się więc przy tym ostatnim znaczeniu. Wydaje się, że sam Burawoy optowałby za takim wyborem: „Podstawowym elementem składowym tej [globalnej] mozaiki jest socjologia narodowa, jako że to naród od zawsze stanowił główny punkt odniesienia dla socjologii” (Burawoy, 2010, s. 4). Koncepcję „ograniczonego wpływu” wyrosłą z "metodologicznego nacjonalizmu” kilkakrotnie krytykował w ostatnim czasie Ulrich Beck (Beck, 2006). Ale wyobrażenie o życiu społecznym ograniczonym granicami danego państwa narodowego jest wciąż żywe, czego dowodem jest nie tylko zacytowany fragment, ale również spis treści omawianego opracowania. Wystarczy popatrzyć na tytuły rozdziałów w tomie drugim, poświęconym Azji. Mamy więc „socjologię bangladeską”, „socjologię indyjską”, „socjologię turecką”, „socjologię kuwejcką”, „socjologię armeńską” czy „socjologię azerbejdżańską”. W takim ujęciu granice państw narodowych definiują zasięg systemów socjologii.

Ale co tak naprawdę znaczy termin „lokalny system socjologii”? Dla przykładu posłużę się nazwą krainy wymyślonej dla podobnych celów przez polskiego filozofa Leszka Kołakowskiego - mowa tu o Lailonii (Kołakowski, 1989). A zatem, co mogłoby znaczyć określenie „lailońska socjologia”? Pierwsze znaczenie jest oczywiste: jest to socjologia w Lailonii, studiowana i uprawiana na lailońskich uniwersytetach i w lailońskich instytucjach badawczych. To najczęstszy temat nudnych sprawozdań socjologicznych. $\mathrm{Na}$ tym poziomie instytucjonalnym i organizacyjnym trudno wyróżnić znaczącą liczbę cech warunkowanych przynależnością narodową, co ma związek z dużym podobieństwem ośrodków badawczych wynikłym z procesów globalizacyjnych. Drugie znaczenie odnosi się do materiałów socjologicznych, tworzonych i publikowanych w języku lailońskim. Jest to wyłącznie kwestia lingwistyczna, która nie ma nic wspólnego z lokalną oryginalnością. Wystarczy przetłumaczyć dany tekst na inny język, by przekonać się, że przekład ma identyczny wydźwięk. W tym miejscu warto wspomnieć o rzekomym imperialistycznym charakterze języka angielskiego. Zamiast cieszyć się z tego, że dzięki globalizacji jeden język obcy pozwala nam korzystać ze światowego dorobku akademickiego, w tym 
ze wszystkich ważnych książek z dowolnej epoki, niektórzy marzą o odbudowie wieży Babel, odrzucając język angielski jako rzekome narzędzie dominacji, ucisku, wykluczenia i wszelkich innych bezecności. Im szybciej socjolodzy z Lailonii zaczną pisać i publikować po angielsku, tym lepiej dla nich i dla socjologii w ogólności. Trzecie znaczenie wiąże się z socjologią uprawianą przez Lailończyków, rodzimych mieszkańców krainy. Tymczasem społeczność akademicką cechuje już od czasów średniowiecza spora mobilność, a w epoce globalizacji socjolodzy ustawicznie się przemieszczają, odwiedzają różne kraje, pozostają w nich tymczasowo lub na stałe, a co za tym idzie, ich narodowość przestała definiować ich jako naukowców. Omawiana kwestia związana jest z doktryną „wewnętrzności”, która została w przekonujący sposób zdezawuowana już przez Roberta K. Mertona (Merton, 1972), argumentującego, że rzeczywistość społeczna nie może być diagnozowana od wewnątrz. Warto natomiast sięgnąć po metodę przeciwną, to jest „zewnętrzność”. To przecież Francuz, Alexis de Tocqueville, jest autorem niezrównanej analizy amerykańskiej demokracji, a z kolei Szwed, Gunnar Myrdal, opisał istotę amerykańskiego problemu rasowego lepiej niż sami Amerykanie. Czwarte ze znaczeń dotyczy socjologii opisującej stosunki społeczne w Lailonii. Ta uwaga może wydać się banalna, ale większość socjologów zdobywa osobiste doświadczenie i dowody empiryczne w swoich własnych krajach. A jednak gdy lailońscy socjologowie poprzestaną na badaniu miejscowego spoŁeczeństwa, przestaną być socjologami w prawdziwym tego słowa znaczeniu. Jeśli ich wiedza ograniczyłaby się do własnego społeczeństwa, ich praca nabrałaby charakteru badań statystycznych i - w moim rozumieniu - utraciłaby cechy prawdziwej socjologii. Z poszerzaniem wiedzy socjologicznej mamy do czynienia jedynie wtedy, gdy socjologowie formułują na podstawie danych lokalnych ogólne wnioski, będące wkładem do dyskusji o uniwersalnych mechanizmach rządzących życiem społecznym. Teorie społeczne i metody badawcze socjologii nie mają nigdy charakteru lokalnego pomimo faktu, że są tworzone w oparciu o lokalne obserwacje i doświadczenia. Od socjologów spoza Europy i Ameryki powinniśmy oczekiwać przede wszystkim ustaleń faktograficznych, heurystycznej intuicji oraz modeli i hipotez kształtowanych w kontekście lokalnym, a więc, ogólnie rzecz biorąc, rzeczywistego wkładu w pulę uniwersalnej wiedzy socjologicznej, który pozwoliłby na weryfikację i rozbudowę istniejących teorii. Wszystkie te założenia mieszczą się jednak w „programie minimum socjologii globalnej”, z którym w pełni się zgadzam.

Piąty kontekst pojęcia „Lailońska socjologia” odnosi się do pracy badawczej dotyczącej problemów społecznych występujących w Lailonii. Rzecz jasna, poszczególne kraje różnią się między sobą, jeśli chodzi o nękające je bolączki. Różnice w zakresie poziomu rozwoju ekonomicznego, ustroju politycznego, dziedzictwa kulturalnego i doświadczeń historycznych przekładają się na odmienną wagę konkretnych kwestii socjologicznych. Problem ważny z perspektywy mieszkańców Nigerii może nie mieć istotnego znaczenia dla Holendrów. Jedne zagadnienia stają się aktualne, inne odchodzą w zapomnienie. Problemy społeczne nigdy jednak nie są całkowicie wyjątkowe dla danego obszaru geograficznego. Chcąc się z nimi zmierzyć, nie należy konstruować „lokalnych” teorii lub metod, ale raczej uznać specyficzne uwarunkowania lokalne za dodatkowe okoliczności, do których 
można dopasować standardowe narzędzia socjologiczne i które mogą stanowić punkt wyjścia analizy odwiecznych problemów struktury społecznej, zmian społecznych i roli aktywności człowieka, a tym samym kontekst uniwersalnych teorii dotyczących prawidłowości i mechanizmów życia społecznego.

Szósty aspekt „socjologii lailońskiej” to lokalność, a więc nastawienie na analizę specyficznych problemów o zasięgu lokalnym z zamiarem ich ograniczenia lub eliminacji na drodze reformy społecznej. Tego rodzaju działalność jest tożsama z „socjologią polityczną” Burawoya, która w tradycyjnym ujęciu nosi nazwę „socjologii stosowanej”. Jedna z podstawowych zasad logiki naukowej głosi, że fakty lub dane nie mogą być same w sobie źródłem postulatów co do praktyki. Fakty i dane muszą zostać zestawione z kontekstem określonej teorii, jasno sformułowanej lub zaledwie orientacyjnie nakreślonej. Tylko w takim układzie stają się elementami stanu wyjściowego, wraz z twierdzeniami teoretycznymi dotyczącymi prawidłowości lub mechanizmów sugerujących możliwe wyniki i postulaty. Dla przykładu, terapia medyczna nie jest formułowana jedynie w oparciu o pomiar temperatury pacjenta lub choćby najdokładniejsze badanie rezonansu magnetycznego. Aby opracować skuteczną terapię, należy taką diagnostykę zestawić z teoriami w zakresie rozmaitych schorzeń i mechanizmów funkcjonowania organizmu. To samo dotyczy socjologii stosowanej. Aby mogła być uznana za metodę naukową, musi odnosić się do zbioru uniwersalnych teorii społecznych, a nie do teorii „lokalnych” o doraźnym charakterze. Wyobraźmy sobie, co by się stało, gdyby pacjenci konsultowani byli w oparciu o teorie anatomiczne i medyczne różniące się w zależności od szpitala. Naukowcy parający się socjologią stosowaną powinni uwzględniać istniejący kanon wiedzy socjologicznej. W przeciwnym razie, jeśli ich propozycje nie bazują na istniejących teoriach, uznać należy, że taka działalność nie ma wiele wspólnego z socjologią polityczną, co najwyżej zasługując na miano intuicji politycznej.

Te same argumenty da się zastosować w odniesieniu do wszelkich „lokalnych” nurtów socjologii, a więc doktryn o zasięgu ograniczonym do jednego regionu, kontynentu lub cywilizacji. Na świecie występuje wiele środowisk społecznych oddzielonych od siebie ze względu na rozmaite kryteria, ale nie znaczy to, że istnieje wiele systemów socjologii. Wielu autorów esejów ze zbioru Facing an Unequal Word twierdzi, że proces globalizacji socjologii nie jest zupełny, lecz ja twierdzę, iż proces ten został zakończony, o ile traktujemy socjologię jako dyscyplinę naukową. Nauka ma z założenia charakter globalny (uniwersalny). Była globalna na długo przed tym, zanim rozpoczęła się globalizacja spoŁeczna, a nawet od samego początku istnienia wspólnoty ludzkiej, ponieważ jej celem jest poszukiwanie „uniwersalnej prawdy”, czyli prawidłowości i mechanizmów rządzących rzeczywistością. Kopernik i Kepler rozwijali globalną (uniwersalną) astronomię, z kolei Newton i Faraday popychali naprzód globalną (uniwersalną) fizykę. W podobny sposób socjologia od zawsze uzasadniała swoje miejsce pośród dziedzin nauki dążeniem do wyjawienia uniwersalnych zasad ludzkiego współżycia. Apel o tworzenie alternatywnych, lokalnych systemów socjologicznych jest przejawem antynaukowego obskurantyzmu. 
Istnieje wiele różnych społeczeństw, ale tylko jedna socjologia - jedna nauka społeczna znajduje zastosowanie w wielu rozmaitych środowiskach społecznych.

\section{Marzenie o socjologii globalnej}

Trzecim filarem ideologii wyłożonej w omawianym opracowaniu jest postulat wdrożenia koncepcji socjologii globalnej rozumianej jako egalitarny konglomerat poszczególnych lokalnych systemów socjologii. Socjologia globalna nie może być tworzona odgórnie, poprzez narzucanie europejskich i amerykańskich idei i metod. Postulat ten głosi potrzebę oddolnego kształtowania socjologii poprzez współdziałanie lokalnych systemów socjologii nakierowane na opór wobec „socjologii głównego nurtu” i tworzenie „socjologii alternatywnej" - jest to rzeczywiście rewolucyjna propozycja.

Jako student byłem poddawany indoktrynacji w duchu marksizmu-leninizmu, który nieodparcie kojarzy mi się z logiką omawianego programu. Wystarczy przyjrzeć się stosownym przykładom. Oto pierwsza teza Burawoya: socjologia nie jest celem samym w sobie, jest odzwierciedleniem interesów społeczeństwa obywatelskiego i tylko w tym kontekście może analizować rynek i państwo. Celem tego jest demaskowanie „ekspansji tych instytucji, zagrażającej społeczeństwu obywatelskiemu, samej socjologii i zdolności obrony wspólnoty społecznej przed, na przykład, dewastacją środowiska naturalnego czy degradacją pracy ludzkiej” (Burawoy, 2010, s. 25). Czy nie jest to echo marksistowskiej „perspektywicznej” socjologii wiedzy, która zakłada, iż jedynie świadomość proletariatu jest w stanie pojąć istotę wyzysku i konieczność samoobrony przed zakusami kapitalizmu. Teza numer dwa: „Wraz z globalizacją rynków również socjologia zaczęła odnosić się do kontekstu ogólnoświatowego, stając się elementem globalnego społeczeństwa obywatelskiego, łączącego wspólnoty, organizacje i ruchy ponad granicami narodowymi" (Burawoy, 2010, s. 25). Socjolodzy wszystkich krajów, łączcie się, nie macie nic do stracenia poza swoim statusem naukowym! Czy nie jest to przypadkiem parafraza końcowego zdania Manifestu komunistycznego? Teza numer trzy: „Skoro socjologia może uzyskać status dziedziny kolektywnej, czy w takim razie jest w stanie wyjść poza ramy obrony własnych interesów - choć rola ta jest oczywiście ważna - i zaangażować się w walkę z problemami społecznymi o znaczeniu globalnym ?" (Burawoy, 2010, s. 26). 0 tak, proletariusze powinni porzucić wąską perspektywę związków zawodowych, zastępując ją prawdziwą świadomością klasową, tak jak postulowali to Lenin i Lukács.

\section{Precz z utopią}

Takie porównania są jak najbardziej uprawnione. Inspiracja może pochodzić z różnych źródeł, natchnienie przychodzi przy lekturze rozmaitych książek. Problem polega na tym, że rewolucyjna ideologia globalnej socjologii, którą przesycone jest omawiane opracowanie, opiera się na trzech fałszywych założeniach. 
Pierwszym z nich jest dążenie do egalitaryzmu w dziedzinie, która ze swej natury ma charakter elitarny, to jest w nauce. Wszyscy doskonale zdajemy sobie sprawę - nawet jeśli zaprzeczamy temu z uwagi na poprawność polityczną - że są wielcy uczeni, dobrzy uczeni, przeciętni uczeni, kiepscy uczeni i osoby udające uczonych. Wiemy, że są czołowe uniwersytety, średnie uniwersytety, złe uniwersytety i ośrodki, które są uniwersytetami tylko z nazwy. Na tej samej zasadzie pewne kraje zajmują czołowe pozycje w rankingu naukowym, kolejne mają na swym koncie drugorzędne i raczej wtórne osiągnięcia, a w jeszcze innych znaczenie nauki jest marginalne lub jest ona w ogóle nieobecna. Powyższe prawidłowości odnoszą się również do socjologów, ośrodków badań socjologicznych i poszczególnych krajów, w których praktykowana jest socjologia. Ponownie powtórzę moje hasło: „perfekcja jest ważniejsza od równowagi” - drugi błąd polega na nieprawidłowej interpretacji różnorodności i relatywizmu. Społeczeństwa są zróżnicowane, nieraz w znacznym stopniu, za sprawą szeregu odmiennych uwarunkowań i okoliczności. Nie znaczy to jednak, że istnieje potrzeba tworzenia różnych systemów socjologii odnoszących się do poszczególnych sytuacji lokalnych. Prawidłowości i mechanizmy funkcjonowania i przemian wspólnoty ludzkiej są niezmienne, niezależnie od społeczeństwa.

Uwarunkowania lokalne są swego rodzaju poligonem, pozwalającym korygować i uzupełniać uniwersalną wiedzę socjologiczną. To właśnie dlatego tak dużą rolę odgrywa socjologia porównawcza, popularyzowana przez wielu badaczy, od Augusta Comte’a do Alexa Inkelesa i Masamichiego Sasakiego (Inkeles \& Sasaki, 1996). Sytuacja lokalna nie powinna zaś służyć jako pretekst do konstruowania oddzielnego systemu socjologii, koncentrującego się na jednym społeczeństwie. Jeszcze raz powtórzę: jeden system socjologii ma zastosowanie do wielu środowisk społecznych.

Trzeci błąd to mieszanie ze sobą dwóch różnych faz analizy socjologicznej: fazy heurystycznej i fazy dowodowej. Badania empiryczne i formułowanie teorii mogą być inspirowane najrozmaitszymi okolicznościami. Słynna legenda mówi o Newtonie, który pod wpływem uderzenia spadającym z drzewa jabłkiem opracował teorię grawitacji. Jeśli chodzi o socjologię, źródłem inspiracji są przede wszystkim osobiste doświadczenia socjologów należących do określonych wspólnot społecznych i działających w konkretnym czasie historycznym. W kontekście heurystyki najbardziej istotne systemy socjologiczne są często autobiografiami ich twórców. Wszyscy jesteśmy głęboko przesiąknięci przynależnością narodową, a także określonymi wartościami kulturalnymi, wierzeniami religijnymi, stereotypami, wyobrażeniami i ideologiami. Nawiasem mówiąc, im silniejsza jest taka identyfikacja, tym lepiej. Dzieje się tak, ponieważ świadomość lokalna przekłada się na orientację w miejscowych problemach wymagających uwagi oraz na zdolność formuŁowania hipotez. Tymczasem w fazie dowodowej trzeba zastąpić przeczucia empirycznie potwierdzonymi faktami, a hipotezy muszą ustąpić pola argumentacji teoretycznej i uzasadnionym prognozom. Na tym etapie sięgamy po uniwersalne narzędzia metodologii socjologicznej i do zbioru teorii społecznych, wybierając spośród nich te metody i koncepcje, które pozwolą uzasadnić i przetestować nasze twierdzenia w zakresie wiedzy 
socjologicznej. Jeśli chodzi o inspiracje i przeczucia, odmienność perspektyw jest czymś naturalnym. Jednocześnie nie możemy tracić z oczu nadrzędnego celu, którym jest poszukiwanie uniwersalnej prawdy poprzez stosowanie uniwersalnych standardów i kryteriów metodologii socjologicznej. Jeden z prekursorów socjologii, których określa się sarkastycznie mianem „tak zwanych klasyków” (Burawoy, 2010, s. 13), wyraził się jasno na ten temat:

„Nadal obowiązuje zasada, iż dany dowód jest zgodny z systemem naukowym tylko wtedy, gdy jego poprawność jest uznawana przez wszystkich, w tym na przykład Chińczyków, a ściślej rzecz ujmując, dowód taki musi mieć odpowiedni potencjał we wspomnianym zakresie, choć kryterium to jest nieraz nieosiągalne ze względu na nieścisłe dane" (Weber, 1949, s. 28).

Zamiast ignorowania tez „tak zwanych klasyków” proponowałbym - jako odtrutkę na nieszczęsny projekt globalnej socjologii i lokalnych systemów socjologicznych - uważną lekturę ich dzieł, w szczególności Metodologii nauk społecznych Maxa Webera (wyd. amerykańskie: Weber, 1949) i Zasad metody socjologicznej Emile’a Durkheima (wyd. amerykańskie: Durkheim, 1962). Nie ma potrzeby korzystać z ich anglojęzycznych edycji; dla tych, którzy chcieliby uniknąć kontaktu z „językowym imperializmem”, dostępne są wydania w wielu różnych językach.

„Program maksimum socjologii globalnej” zaprezentowany w omawianym opracowaniu to nowa socjologiczna utopia. Nawet jeśli intencje towarzyszące jego sformułowaniu były szlachetne, manifest ten nie nadaje się do zaakceptowania. Jego założenia są nierealne, czego przyczyny zaprezentowałem w niniejszej recenzji. Nasuwa się w tym miejscu przysłowiowe szukanie czarnego psa w ciemnym pokoju, którego w rzeczywistości tam nie ma. Jedyną czytelną i rozsądną propozycją jest koncepcja zwana przeze mnie „programem minimum globalnej socjologii", czyli konsekwentna próba poszerzania wiedzy socjologicznej przy wykorzystaniu inspiracji pochodzących ze wszystkich krajów świata, różnorodnych społeczeństw, kultur i cywilizacji oraz wciągania socjologów z krajów o mniej rozwiniętych tradycjach socjologicznych w ogólnoświatowy nurt uznanych i udowodnionych metod i teorii o charakterze uniwersalnym. Te doświadczenia i inspiracje znajdą najlepsze zastosowanie przy testowaniu, korygowaniu i rozszerzaniu uniwersalnego kanonu socjologii, natomiast nie powinny służyć jego zwalczaniu z pobudek ideologicznych.

„Program minimum” był i jest realizowany, a ISA, patron omawianego opracowania, ma do odegrania ważną rolę $w$ tym zakresie. Z resztą kompilacji kontrastuje końcowy rozdział ostatniego tomu, w którym Arturo Rodriguez Morato, były wiceprezes ISA ds. badań, daje odpór rewolucyjnemu zapałowi redaktorów i pozostałych autorów, prezentując sprawozdanie na temat działalności ISA, dotychczasowych osiągnięć tej organizacji i planowej metody wdrożenia „programu minimum”. Po lekturze tysiąca stron fragment ten wydaje się oazą zdrowego rozsądku, choć i tak nie wynagradza to czasu straconego na lekturę omawianej pozycji. Zaprezentowany radykalizm nie służy dobrze rozwijającym się systemom socjologicznym w krajach pozostających na uboczu światowej socjologii, jako że zachęca lokalnych badaczy do tworzenia ideologicznych manifestów i poświęcania się 
skazanym na niepowodzenie próbom opracowania „alternatywnej socjologii”, co może ich odciągać od standardowej pracy naukowej, za pośrednictwem której mają szansę na wprowadzenie lokalnych doświadczeń i inspiracji do głównego nurtu socjologii.

Tłumaczenie: Borys Walczyna

\section{Bibliografia:}

Akiwowo Akinsolo, A. (1986). Contributions to the sociology of knowledge from an African oral poetry. International Sociology, 1(4), 343-358.

Al-Naser, F. (2010). Challenges to sociology in the Gulf States: a case study of Kuwait. W M. Burawoy, M. Chang, \& M. Fei-yu Hsieh (Red.), Facing an unequal world: challenges for a global sociology (T. 2, ss. 132-138). Taipei: Institute of Sociology at Academia Sinica, Council of National Associations of the International Sociological Association, Academia Sinica.

Alatas, S. F. (2010). The definition and types of alternative discourses. W M. Burawoy, M. Chang, \& M. Fei-yu Hsieh (Red.), Facing an unequal world: challenges for a global sociology (T. 2, ss. 139-157). Taipei: Institute of Sociology at Academia Sinica, Council of National Associations of the International Sociological Association, Academia Sinica.

Beck, U. (2006). Cosmopolitan vision. Cambridge (Mass.): Cambridge University Press.

Burawoy, M. (2005). 2004 American Sociological Association Presidential Address: for public sociology. The British Journal of Sociology, 56(2), 259-294.

Burawoy, M. (2010). Facing an unequal world: challenges for a global sociology. W M. Burawoy, M. Chang, \& M. Fei-yu Hsieh (Red.), Facing an unequal world: challenges for a global sociology (T. 1, ss. 3-27). Taipei: Institute of Sociology at Academia Sinica, Council of National Associations of the International Sociological Association, Academia Sinica.

Burawoy, M., Chang, M., \& Fei-yu Hsieh, M. (Red.). (2010). Facing an unequal world: challenges for a global sociology (T. 1-3). Taipei: Institute of Sociology at Academia Sinica, Council of National Associations of the International Sociological Association, Academia Sinica.

Chang, M., Chang, Y., \& Tang, C. (2010). Indigenization, institutionalization, and internationalization: tracing the paths of the development of sociology in Taiwan. W M. Burawoy, M. Chang, \& M. Fei-yu Hsieh (Red.), Facing an unequal world: challenges for a global sociology (T. 2, ss. 158-191). Taipei: Institute of Sociology at Academia Sinica, Council of National Associations of the International Sociological Association, Academia Sinica.

Crothers, C. (2010). New Zealand sociology in a neoliberal era: strands of political economy in New Zealand social science. W M. Burawoy, M. Chang, \& M. Fei-yu Hsieh (Red.), Facing an unequal world: challenges for a global sociology (T. 2, ss. 228-243). Taipei: Institute of Sociology at Academia Sinica, Council of National Associations of the International Sociological Association, Academia Sinica.

Durkheim, E. (1962). The rules of sociological method. (S. A. Solovay \& J. H. Mueller, Tłum., G. E. G. Catlin, Red.). Glencoe: The Free Press.

Fritz, J. M. (2010). Practical responses to the challenges for sociology in the face of global inequality? W M. Burawoy, M. Chang, \& M. Fei-yu Hsieh (Red.), Facing an unequal world: challenges for a global sociology (T. 3, ss. 279-282). Taipei: Institute of Sociology at Academia Sinica, Council of National Associations of the International Sociological Association, Academia Sinica.

Giddens, A. (2009). The politics of climate change. Cambridge (Mass.): Polity Press.

Goffman, E. (1963). Stigma: notes on the management of spoiled identity. Englewood Cliffs, New Jersey: Prentice-Hall. 
Inkeles, A., \& Sasaki, M. (1996). Comparing nations and cultures. Englewood Cliffs, New Jersey: Prentice-Hall.

Kołakowski, L. (1989). Tales from the Kingdom of Lailonia and the key to Heaven. (A. Kołakowska \& S. Attanasio, Tłum.). Chicago: University of Chicago Press.

Lee, Y.-T. (2010). Challenges facing human society in the 21st century. W M. Burawoy, M. Chang, \& M. Fei-yu Hsieh (Red.), Facing an unequal world: challenges for a global sociology (T. 1, ss. 28-34). Taipei: Institute of Sociology at Academia Sinica, Council of National Associations of the International Sociological Association, Academia Sinica.

Levi-Strauss, C. (1955). Tristes tropiques. Paris: Librairie Plon.

Mapadimeng, M. S. (2010). South African sociology: current challenges and future implications: a review and some empirical evidence from the 2007 National Survey of Sociology Departments. W M. Burawoy, M. Chang, \& M. Fei-yu Hsieh (Red.), Facing an unequal world: challenges for a global sociology (T. 1, ss. 213223). Taipei: Institute of Sociology at Academia Sinica, Council of National Associations of the International Sociological Association, Academia Sinica.

Merton, R. (1972). Insiders and outsiders. The American Journal of Sociology, 78(1), 9-47.

Mucha, J. (2010). Sociology in Eastern Europe or East European sociology: historical and present. W M. Burawoy, M. Chang, \& M. Fei-yu Hsieh (Red.), Facing an unequal world: challenges for a global sociology (T. 3, ss. 187-206). Taipei: Institute of Sociology at Academia Sinica, Council of National Associations of the International Sociological Association, Academia Sinica.

Patel, S. (Red.). (2010). ISA handbook of diverse sociological traditions. London: Sage.

Sztompka, P. (1999). Trust: a sociological theory. Cambridge (Mass.): Cambridge University Press.

Sztompka, P. (2006). Trust: a sociological theory (2. wyd.). Pekin: Zonghua Book Company.

Weber, M. (1949). The methodology of the social sciences. (E. Shils \& H. Finch, Tłum.). New York: The Free Press.

\section{Another sociological utopia}

Keywords: Michael Burawoy; International Sociological Association; social sciences; domination; colonialism; imperialism; globalisation; the Western world; localness; global sociology; utopia

This is an Open Access article distributed under the terms of the Creative Commons Attribution 3.0 PL License, which permits redistribution, commercial and non-commercial, provided that the article is properly cited.

www.creativecommons.org/licenses/by/3.0/pl

(c) The Author(s) 2014

Publisher: Institute of Slavic Studies PAS [Wydawca: Instytut Slawistyki PAN]

Reprinted by Permission of SAGE Publications.

DOI: $10.11649 /$ slh.2014.011 